\title{
CARBONATE PRECIPITATION, U SERIES DATING, AND U-ISOTOPIC VARIATIONS IN A HOLOCENE TRAVERTINE PLATFORM AT BAD LANGENSALZA - THURINGIA BASIN, GERMANY
}

\author{
Norbert FRANK ${ }^{1,3}$, Bernd KOBER ${ }^{2} \&$ Augusto MANGINI ${ }^{1}$
}

\begin{abstract}
Travertine and calcareous tufa deposits, are important archives for Quaternary continental climate and archaeology. Here we present a comprehensive study on Holocene travertine deposition in the Thuringia basin based on a detailed survey of U-series measurements and dating that demonstrates rapid accumulation of carbonate during the early Holocene until 8000 years (up to $8 \mathrm{~mm} \mathrm{yr}^{-1}$ ) followed by significant change in travertine accumulation that ended around 5800 years BP at the investigated site. We further demonstrate that systematic changes of the U-isotopic composition through time occur in agreement with major changes in travertine accumulation and texture, which are likely to reflect changes of spring water U-isotopic composition rather than U-series system opening or contamination with non-carbonate particles.
\end{abstract}

Key words: Travertine, Thuringia, Holocene, U-series, Uranium isotopes.

\section{RÉSUMÉ}

PRÉCIPITATION DE CARBONATE, DATATION U/TH ET VARIATIONS ISOTOPIQUES DE L'URANIUM D'UNE PLATEFORME DE TRAVERTIN HOLOCÈNE À BAD LANGENSALZA - BASSIN DE THURINGE, ALLEMAGNE

Les travertins et les tufs calcaires constituent des archives importantes pour les études sur le climat continental quaternaire et l'Archéologie. Nous présentons l'étude de la formation d'un travertin holocène du bassin de Thuringe, basée sur un exposé détaillé des données uranium-thorium et des âges U-Th obtenus, qui démontrent une accumulation rapide du carbonate pendant le début de l'Holocène jusque vers 8000 ans (jusqu'à 8 mm par an) suivie par un changement significatif dans le rythme d'accumulation du travertin qui s'achève vers 5800 ans BP sur le site étudié. Nous démontrons ensuite que les changements systématiques dans la composition isotopique de l'uranium au cours du temps sont en accord avec les variations majeures de texture et d'accumulation du travertin et reflètent les changements de composition isotopique de l'uranium des eaux de source plutôt qu'une ouverture du système des séries de l'uranium voire une contamination par des particules non carbonatées.

Mots-clés : Travertin, Thuringe, Holocène, U-Th, isotopes de l'Uranium.

\section{1 - INTRODUCTION}

In the past 25 years researchers have shown that continental carbonate deposits, such as travertine can be absolutely dated to about 350,000 years before present by means of the ${ }^{230} \mathrm{Th} / \mathrm{U}$ disequilibrium method (Blackwell \& Schwarcz, 1986; Brunnacker et al., 1983; Frank et al., 2000; Harmon et al., 1980; Mallick \& Frank, 2002; Schwarcz et al., 1988; Srdoc et al., 1994; Sturchio et al., 1994). This method is based on the fact that $\mathrm{U}$-isotopes are easily weathered from an aquifer host rock and are then transported within groundwater, while the radioactive daughter product ${ }^{230} \mathrm{Th}$ is highly particle reactive and thus not abundant in groundwater. Uranium becomes co-precipitated during accumulation of secondary carbonate as travertine from organic and inorganic calcite or even aragonite precipitation. Subsequently, ${ }^{230} \mathrm{Th}$ is produced in a travertine layer from decay of ${ }^{234} \mathrm{U}$, beginning with the formation of the layer.

Assuming closed system behavior of the travertine and no initial ${ }^{230} \mathrm{Th}$, one can determine the age of a travertine or calcareous tufa deposit according to the radioactive decay by measuring the present-day activity ratios of $\left({ }^{230} \mathrm{Th} /{ }^{238} \mathrm{U}\right.$ ) and $\left({ }^{234} \mathrm{U} /{ }^{238} \mathrm{U}\right.$ ) (Ivanovich \& Harmon, 1992). The $\left({ }^{234} \mathrm{U} /{ }^{238} \mathrm{U}\right)$ activity ratio is henceforth given in per mil $(\% o)$ as $\delta^{234} \mathrm{U}$, where $\left.\delta^{234} \mathrm{U}=\left(\left({ }^{234} \mathrm{U} /{ }^{238} \mathrm{U}_{\text {measured }}\right) /{ }^{234} \mathrm{U} /{ }^{238} \mathrm{U}_{\text {equilibrium }}\right)-1\right) * 1000$. ${ }^{234} \mathrm{U} /{ }^{238} \mathrm{U}_{\text {equilibrium }}$ is equal to 1 as an activity ratio and $54.891 \cdot 10^{-6}$ as an atomic ratio (Cheng et al., 2000).

The age uncertainty of this ideal scenario is given solely by the precision and reproducibility of the measurement of both activity ratios and the precision to which the decay constants are known. However, travertine contains aluminosilicate and limestone particles as well as organic matter, which contribute to the overall

\footnotetext{
${ }^{1}$ Institut für Umweltphysik, Universität Heidelberg, Im Neunehimer Feld 229, D-69120 Heidelberg, Germany

${ }^{2}$ Institut für Umwelt Geochemie, Im Neuenheimer Feld 234, D-69120 Heidelberg, Germany

${ }^{3}$ Laboratoire des Sciences du Climat et de L'Environnement-IPSL, Unité mixte CEA-CNRS-UVSQ, Bât.12, Avenue de la Terrasse, 91198 Gif-surYvette, France. E-mail: norbert.frank@ Isce.cnrs-gif.fr
} 
amount of U-series nuclides. Moreover initial nondetrial ${ }^{230} \mathrm{Th}$ can be a potential problem and post depositional infilling with later carbonate generations in the initial pore space and dead volume, mostly as secondary spar and especially carbonate cement and detritus is frequent. Thus, any contamination strongly influences the accuracy of an age determination. In addition, even after secondary infilling of the pore space and dead volume travertine remains a highly porous rock that is subject to weathering resulting in dissolution and re-precipitation of carbonate, redistribution of $\mathrm{U}$-series daughters through recoil processes, and $\mathrm{U}$ and Th loss or uptake. Classic Karst phenomena such as dissolution are widespread in travertine bodies, as indicated by the frequent presence of caves (Adam, 1986; Brunnacker et al., 1982; Frank, 1997; Grewe, 1987; Reiff, 1986; Sommermeier, 1913). In the marine environment the $\mathrm{U}$-isotopic ratio stays constant over long time scales (Henderson, 2002) and it can thus be used to trace U-series system opening. In contrast, in continental carbonates a rapid change of the U-isotopic composition of spring water hinders the use of the initial U-isotopic ratio as a quality control instrument for precise age determination.

To get around these many obstacles, different approaches have been taken. To trace detrital contamination one can use ${ }^{232} \mathrm{Th}$ by either assuming average $\left({ }^{238} \mathrm{U} /{ }^{232} \mathrm{Th}\right)$ activity ratios of continental crust and radioactive equilibrium (basic correction model) (Frank et al., 2000), or by measuring aluminosilicate sediments present at the travertine location (Frank et al., 2000). Studying several coeval samples using so called isochron techniques is more time consuming but yield more sophisticated correction models, as the impact of initial ${ }^{230} \mathrm{Th}$ and detritus ${ }^{230} \mathrm{Th}$ can be corrected and uranium-series open-system behavior may be identified qualitatively if data is not matching a common detritalcarbonate mixing line (Frank et al., 2000; Ludwig \& Titterington, 1994; Schwarcz, 1980; Sturchio et al., 1994). Other chronometers such as ${ }^{231} \mathrm{~Pa} /{ }^{235} \mathrm{U}$ dating may add information on the quality of ages (Frank, 1997), but as the aqueous chemistry of ${ }^{231} \mathrm{~Pa}$ is complex and tracer isotopes such as ${ }^{232} \mathrm{Th}$ are missing to quantify non-carbonate contamination its application to travertine seems so far quite useless.

Despite complex correction models the initial sampling process is a key to obtain precise and accurate ages, as major contaminants and weathering features can be avoided. For high-resolution studies of "young" travertine the stratigaphic position of the samples is also crucial in light of a highly irregular precipitation ranging from almost horizontal layers and small cascades on surfaces having minor slopes, to successive carbonate cascades and mounds on steeper slopes. Recently, Mallick and Frank (Mallick \& Frank, 2002) have attempted to obtain ages using a micro-sampling technique to guarantee the investigation of primary calcite. The results for deposits of 100,000 to $250,000 \mathrm{yrs}$ age are very promising, but beyond this age weathering becomes frequently too important to obtain sufficiently large undisturbed micrite or spar layers (Mallick \& Frank, 2002). For young deposits, analytical efficiency for ${ }^{230} \mathrm{Th}$ measurements was insufficient to work on micro-samples of less than $100 \mathrm{mg}$ size, but micrite dominated and associated pore cement may differ by 800 years in age (Mallick, 2000) (see also tab. 1). Although, the anticipated significant removal of detrital contamination failed, as micro detritus is present on any scale of a travertine deposit and can be barely avoided (Mallick \& Frank, 2002). However, till now the technique to combine detailed petrographic and geochemical studies prior to U-series dating yield the most convincing results for $<250,000$ year old deposits. Moreover, prior investigations of Frank et al. (Frank et al., 2000) and Mallick and Frank (Mallick \& Frank, 2002) have shown that the initial U-isotopic composition varies through time. This can be due to (1) U-series open-system behavior assuming constant U-isotopic composition in groundwater, analogous to U-series system opening in corals (Gallup et al., 2002; Gallup et al., 1994; Henderson \& Slowey, 2000; Scholz et al., 2004; Thompson et al., 2003; Villemant \& Feuillet, 2003) or (2) variable groundwater U-isotopic composition during travertine formation, potentially indicating changes of groundwater residence time, weathering of host rocks, precipitation, and/or source of U-isotopes.

Here we investigate in great detail a travertine deposit that originated during the Holocene to study the complex accumulation pattern in an environment largely free of diagenesis. From such a record we can investigate the relation of initial carbonate precipitation and secondary infilling of initial pore space, and we can further determine the natural variability of the $\mathrm{U}$-isotopic system in travertine to check whether variations observed in nearby older travertine deposits are due to weathering and erosion or reflect natural changes in groundwater composition and regional environmental conditions.

\section{2 - GEOLOGICAL SETTING}

Travertine and calcareous tufa deposits of the Thuringia basin originate from meteoric groundwater running through extended limestone and Keuper formations of the German Triassic (fig. 1). High groundwater $\mathrm{CO}_{2}$ levels are mainly due to decomposition of organic matter in the unsaturated soil within the groundwater formation region, as indicated by average $\delta^{13} \mathrm{C}$ values of calcite of $-7 \pm 1 \%$ (PDB-scale). Bad Langensalza is situated on the slope of the Hainich mountainous region, which has a maximal elevation of $495 \mathrm{~m}$ a.s.l. Today, the Hainich is the largest connected woodland of Germany that has recently become a national park in which the European rain forest can develop without significant anthropogenic influence.

Rainfall in the basin is as low as $500 \mathrm{~mm}$ per year and the regional climate has a more continental character than comparable sites in Central Europe as the 
Thuringia basin is completely surrounded by mountains. Travertine formation could likely take place during episodes of warm climate, during which the mountains were covered with dense woodland as today. During glacial times the region was subject to permafrost and thus carbonate precipitation was inhibited. The travertine body in Bad Langensalza extends down slope over several square kilometers along the river Salza from west through east, with the source of carbonate saturated groundwater near Ufhoven in which so called soil depression springs along the major fault system are still active (springs: small and large Golcke). The travertine extension and texture has been extensively investigated for economic reasons as it is still extracted as a building stone. More than 50 drillings have been performed during the past 3 decades. The travertine itself has formed on a glacial gravel bed of the river Salza and solely in the less thick eastern part of the deposits near the river Unstrut did travertine form on alluvial clays. Its thickness is close to $10 \mathrm{~m}$ in the depression at the City centre of Bad Langensalza. Its texture was subdivided in 3 commercial categories, laminar dense travertine (mostly at the base of the deposits), porous but laminar travertine (centre of the deposits) and loose alluvial mud intersected with travertine and tufa (topmost carbonate layers and most eastern layers). From the description of the drillings those different textures are generally separated by deposition of reed-encrusted travertine and alluvial clays likely precipitated in stagnant waters or during flood events.

At present no carbonate precipitation occurs and the carbonate rich waters are injected in the river Salza, which has cut its bed into the travertine formation. The reason for the lack of modern carbonate precipitation is unknown, but is likely due to either deforestation as a consequence of human activity in this region since preroman time, changes in regional climate and precipitation, or insufficient hydrological activity to further flood the extended travertine body.

Fehler (1998) has found minor cascade structures of less than $1 \mathrm{~m}$ height in the bottom most dense laminar deposits (14 m to about $10 \mathrm{~m}$ depth), while the central layers and the top layers show little indication of cascades probably due to the fact that the initial topography of the valley, especially the slight depression in the City centre has been evened out by carbonate formation. However, it is difficult to reconstruct in great detail the travertine growth and structure given the complexity of the carbonate platform and its extension, as well as the fact that the travertine deposits have been extracted as building stone at least since early medieval times.

Fig. 1: Location of travertine sites Bad Langensalza, Burgtonna, Weimar-Ehringsdorf and Bilzingsleben within the Thuringia Basin. Fig. 1 : Localisation des sites de travertin Bad Langensalza, Burgtonna, Weimar-Ehringsdorf et Bilzingsleben dans le bassin de Thuringe. 


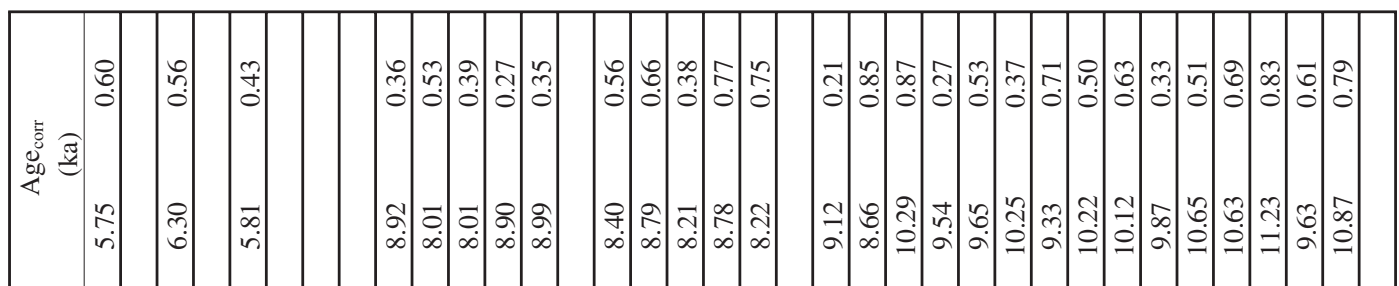

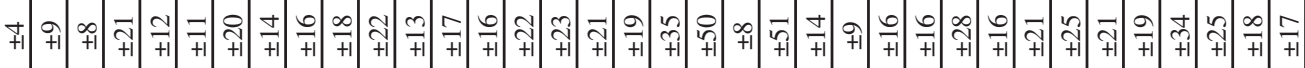

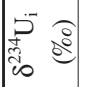

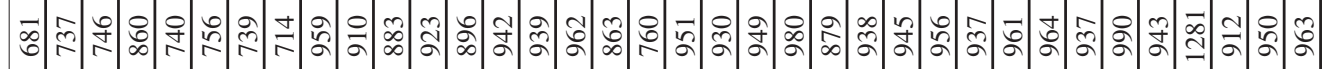

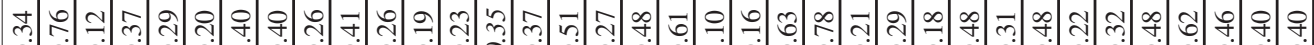

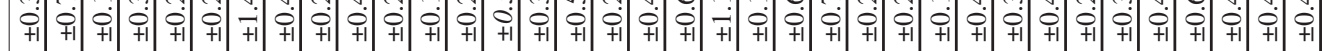
$\underset{8}{8}$

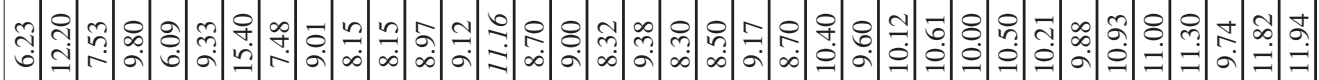

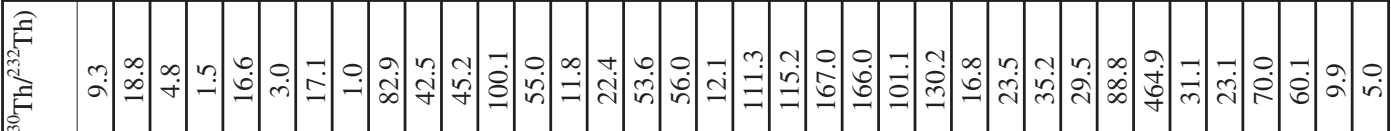

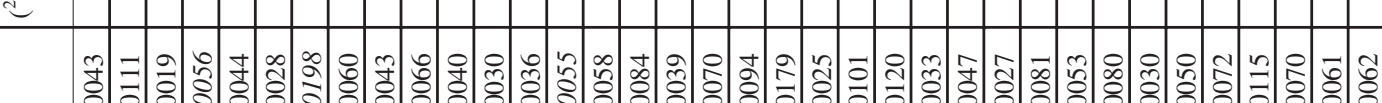

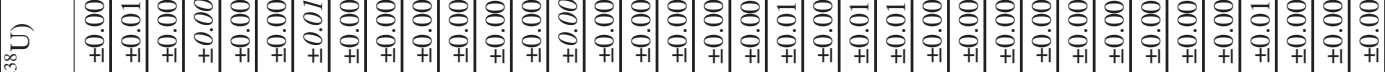

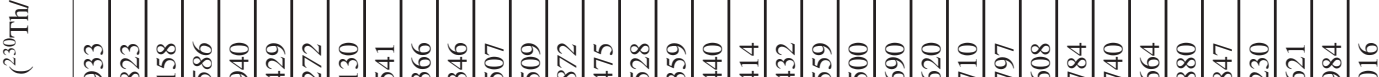

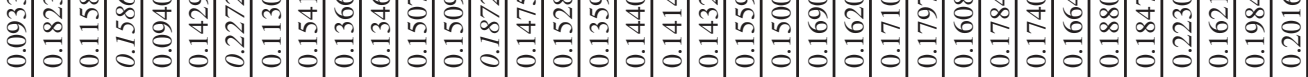

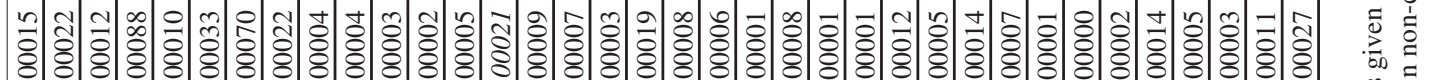

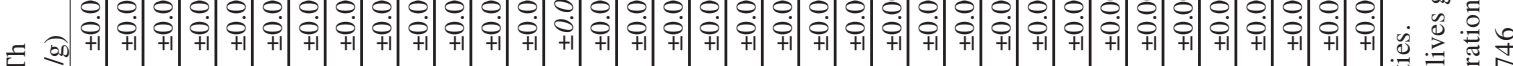

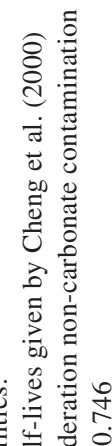

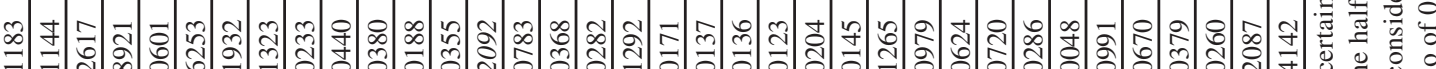

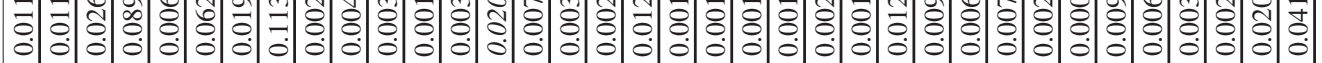

on

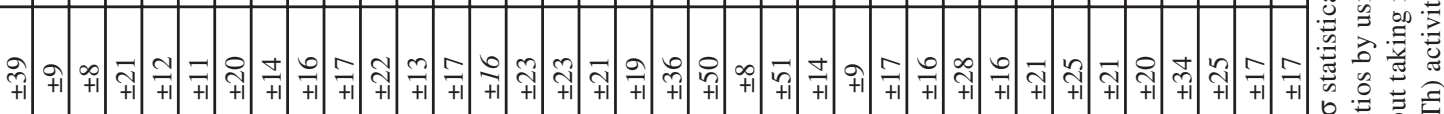
等

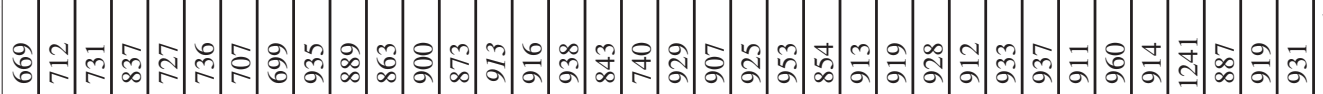

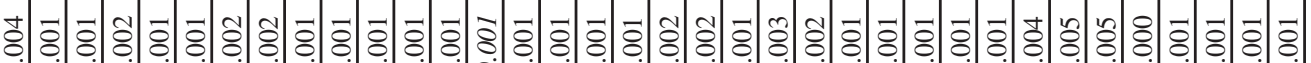
( (5)

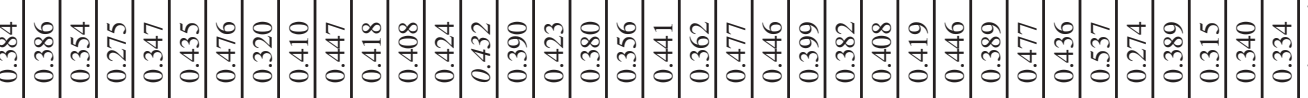

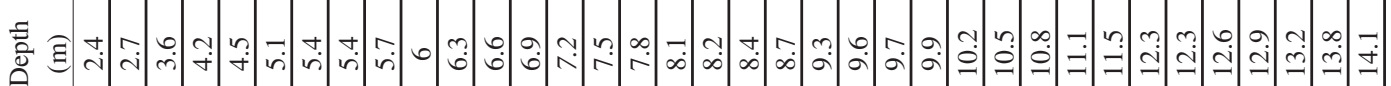

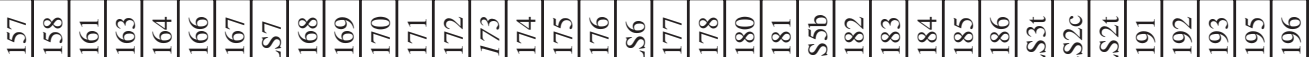




\section{3 - SAMPLES AND METHODS}

For this study we collected travertine and calcareous tufa samples at site Bad Langensalza, in an open quarry in the City centre and from a $14 \mathrm{~m}$ drill core recovered in street Milchgasse about $50 \mathrm{~m}$ away from the main travertine quarry. Both sites are representative for the area of major carbonate deposition as travertine thickness is maximal with almost $10 \mathrm{~m}$ mostly banded laminar carbonate layers. A detailed cross section of the travertine is presented in figure $2 \mathrm{a}$ and the texture of the drill core in figure $2 b$. For our study we collected material mainly from layers where laminar growth bands are dominant, but a few samples of reed-encrusted tufa and one sample of secondary palisade cement were also collected for comparison. Using a titanium-bladed saw we cut off slabs of some $\mathrm{cm}^{3}$ size, which were precleaned using $0.1 \mathrm{~N} \mathrm{HNO}_{3}$ and ultrasound. Samples were then carefully rinsed with Millipore water and dried. Given the young age of the site, we could not apply the micro-sampling technique recently established for older travertine deposits (Mallick \& Frank, 2002), thus solely bulk samples have been used for U-series dating. However, we prepared thin sections on all slabs for polarization microscopy to identify the different calcite phases. The densest structures are micrite and spar, which build up the growth bands without orientation of the primary minerals. All samples show variable amounts of pore fillings with second or third generation calcite as cement. Also, detritus is present in all samples and minor traces of residual organic matter. Aliquots of these bulk samples have been used to perform mass spectrometric U-series dating.

About $300 \mathrm{mg}$ of bulk material was used for U-series dating according to the procedures given in detail in Frank et al. (Frank et al., 2000) and Mallick and Frank (Mallick \& Frank, 2002). Th and U measurements were performed after standard ion exchange chemistry

Fig. 2 A and B: Schematic cross section of the travertine body at Bad Langensalza. A) The orange arrow points out the drill location "Milchgasse" and the sampling at the travertine outcrop nearby. The size of the cross section corresponds to a few kilometers. B) Summary photo of the drill core and description of the travertine texture with depth $(\mathrm{m})$ as obtained from the drill core. The black bar indicates the recovery of travertine material. The observed texture is identical to the one observed in the nearby outcrop.

Fig. 2 A et B : Coupe schématique du dépôt de travertin principal à Bad Langensalza. A) La flèche orange indique la position du forage "Milchgasse" et de la carrière de travertin voisine. B) Photos du forage et description de la texture du travertin par rapport à la profondeur obtenue à partir du forage. La barre noire indique le taux de récupération de matériel. La texture observée est identique à celle de la carrière voisine 
(Frank et al., 2000) on a multi-collector mass spectrometer (Finnigan MAT262). For this study we used a new ${ }^{233} \mathrm{U} /{ }^{236} \mathrm{U}$ double spike (FIZ-1), having a ${ }^{233} \mathrm{U} /{ }^{236} \mathrm{U}$ atomic ratio of $0.008439 \pm 0.000012(2 \sigma$-mean, $\mathrm{N}=20)$ close to the natural ${ }^{234} \mathrm{U} /{ }^{235} \mathrm{U}$ ratio of 0.007568 at radioactive equilibrium of $\left({ }^{234} \mathrm{U} /{ }^{238} \mathrm{U}\right)$. This ${ }^{233} \mathrm{U} /{ }^{236} \mathrm{U}$-spike was calibrated against reference material NBL-112a and contains $49.00 \pm 0.5 \mathrm{ng} \mathrm{g}^{-1}\left[{ }^{236} \mathrm{U}\right]$. The amount of spike was added depending on the sample size to ensure ${ }^{234} \mathrm{U} /{ }^{233} \mathrm{U}$ and ${ }^{235} \mathrm{U} /{ }^{236} \mathrm{U}$ atomic ratios closes to 1 . Measurements of $U$ reference material NBL-112a yield on average $\delta^{234} U$ values of $-38.4 \pm 3.3 \%$ ( $1 \sigma$-STD, $\mathrm{N}=21$ ) for the course of our experiment, using the decay constant of ${ }^{234} \mathrm{U}$ given by Cheng et al. (Cheng et al., 2000). These values agree with recently published values of $-37.6 \pm 1.0 \%$ ( $1 \sigma-S T D)$ and $-36.9 \pm 1.7 \%(1 \sigma-$ STD) by Delanghe et al. (Delanghe et al., 2002), and by Cheng et al. (Cheng et al., 2000). The ${ }^{229}$ Th-spike used has a ${ }^{230} \mathrm{Th} /{ }^{229} \mathrm{Th}$ atomic ratio of $0.0000050 \pm$ $0.0000020(2 \sigma$-mean $)$ and contains $102.94 \pm 0.20 \mathrm{ngg}^{-1}$ [ ${ }^{229} \mathrm{Th}$ ], calibrated against HU-1 reference material by Eisenhauer et al. (Eisenhauer et al., 1996). The external reproducibility of $\mathrm{U}$ concentration measurements is $0.5 \% \circ(2 \sigma)$, and that for Th is $0.6 \%$ o $(2 \sigma)$. All measurements were performed on the electron multiplier using a peak jump routine. Thermal fractionation corrections were carried out for $\mathrm{U}$-isotopes by using the ${ }^{233} \mathrm{U} /{ }^{236} \mathrm{U}$ atomic ratio of the spike. Analytical blanks are very constant and amount to $10 \pm 5$ fg ${ }^{230} \mathrm{Th}, 0.2 \pm 0.1 \mathrm{ng}$ ${ }^{232} \mathrm{Th}$, and $0.1 \pm 0.03 \mathrm{ng}{ }^{238} \mathrm{U}$. These values are negligible considering the Th and $\mathrm{U}$ abundance of our bulk samples.

\section{4 - RESULTS}

The travertine of Bad Langensalza has U concentrations between 0.27 to $0.54 \mu \mathrm{gg}^{-1}$ (tab. 1). The bottom layers between $12.5 \mathrm{~m}$ and $14 \mathrm{~m}$ depth as well as the topmost travertine layers between $2 \mathrm{~m}$ and $5 \mathrm{~m}$ depth have slightly lower $U$ concentrations of average $0.343 \pm 0.036{\mu \mathrm{gg}^{-1}}^{-1}$, if compared to the central travertine body between $5.4 \mathrm{~m}$ and $12.5 \mathrm{~m}$ depth, which has $0.43 \pm 0.04 \mu \mathrm{gg}^{-1}{ }^{238} \mathrm{U}$ (fig. 3a). However, different carbonate precipitates such as laminar travertine, reed-encrusted tufa or pore cement do not exhibit significant differences in U-concentration.

The measured U-isotopic composition of the travertine shows a more pronounced pattern (fig. $3 \mathrm{~b}$ ). From the bottom of the travertine deposit to about $5.4 \mathrm{~m}$ depth the $\left({ }^{234} \mathrm{U} /{ }^{238} \mathrm{U}\right)$ activity ratio is rather constant with values of $1.911 \pm 0.023$, i.e. $\delta^{234} U_{\text {average }}=911 \pm$ $23 \%$ o $(\mathrm{N}=26)$. Secular variations are small $(<40 \%$ ) except for one sample at $12.9 \mathrm{~m}$ depth having a highly elevated value of $\delta^{234} U$ of $1240 \pm 34 \%$ and one sample at $8.2 \mathrm{~m}$ depth having a significantly lower value of $\delta^{234} \mathrm{U}$ of $740 \pm 19 \%$. Above $5.4 \mathrm{~m}$ depth the U-isotopic composition systematically drops to mean values of $\delta^{234} \mathrm{U}_{\text {average }}$ of $727 \pm 50 \%$ o $(\mathrm{N}=8)$. A correlation of $\mathrm{U}$ isotopic composition and U-concentration is not evident.

Measured ${ }^{232} \mathrm{Th}$-concentrations are in general low $\left(<0.02 \mu \mathrm{g} \mathrm{g}{ }^{-1}\right)$ and $\left({ }^{230} \mathrm{Th} /{ }^{232} \mathrm{Th}\right)$ activity ratios are mostly $>30$ (fig. 3c). Only exceptions are one sample from the basal unit of the travertine having $0.04 \mu \mathrm{gg}^{-1}$ ${ }^{232} \mathrm{Th}$ and a few samples from the top having up to

Fig. 3A-C: U-series data. a) U concentration, b) U-isotopic composition, c) total ${ }^{232}$ Th concentration. The scatter and dotted lines corresponds to textural changes in the travertine structure given in the text.

Fig. 3A-C: Mesures U/Th. A) Concentration de l'Uranium, B) composition isotopique de l'Uranium et C) concentration en Thorium total (232Th). 
$0.113 \mu \mathrm{gg}^{-1}{ }^{232} \mathrm{Th}$. In the upper unit carbonate precipitation is intersected with alluvial clays, which causes a large amount of detrital particles in the pore space of the carbonate fabric. In addition loose fine grain carbonate sands are frequently intersected with denser travertine precipitates resulting in a significant loss of material during the drilling of core Milchgasse. Thus, ${ }^{232} \mathrm{Th}$ seems mostly derived from leaching of non-carbonate particles, organic matter and fine grain carbonate sands. However, small amounts of ${ }^{232} \mathrm{Th}$ and henceforth ${ }^{230} \mathrm{Th}$ may result directly from spring waters as Th can be transported within organic complexes or adsorbed to colloids. To test the sensitivity of such noncarbonate contamination on the U-series ages we have used the measured ${ }^{232} \mathrm{Th}$ concentration to correct measured $\left({ }^{230} \mathrm{Th} /{ }^{238} \mathrm{U}\right)$ activity ratios solely for detrital ${ }^{230} \mathrm{Th}$-contamination. We applied a very simplistique correction model (Mallick \& Frank, 2002) taking into consideration a $\left({ }^{230} \mathrm{Th} /{ }^{232} \mathrm{Th}\right)$ activity ratio of detritus of $0.764 \pm 0.25$, which corresponds to the mean continental crust value (Wedepohl, 1995). Then ages and initial U-isotopic composition $\left(\delta^{234} \mathrm{U}_{\mathrm{i}}\right)$ were calculated by using the "ISOPLOT" program provided by K. Ludwig (Ludwig, 2001) and half-lives provided by Cheng et al. (2000). Age uncertainties are calculated from $2 \sigma$ statistical errors of isotopic ratios and further propagating the error of our simple correction model into the age calculation. The influence of non-carbonate contamination on the $\mathrm{U}$ isotopic composition is negligible and was thus not applied here. The applied correction model reduced ages by about 200 years in average and by less than 500 years for $80 \%$ of the data. Thus the influence of non-carbonate contamination is rather small or even insignificant for most of the samples. Furthermore, the application of isochron correction models (Kaufman, 1993; Ludwig \& Titterington, 1994) as frequently applied to contaminated carbonates (Frank et al., 2000; Lin et al., 1996; Sturchio et al., 1994) does not provide significant correlations between isotopic ratios and does thus not identify a significant additional source of Th contamination. However, in 7 cases (see tab. 1) U-series ages have been rejected, due to high analytical uncertainties $(>10 \%)$ and/or because the carbonate fabric did reveal dissolution features, organic matter residues, strong precipitation of Fe-Mn coating, and/or a strong age correction. Dissolution likely causes $U$ leaching and thus $U$ series open system behavior, while non carbonate contamination mostly results in strongly elevated Th values. Five of these samples are from the topmost travertine sequence having the most complex and variable texture and elevated ${ }^{232} \mathrm{Th}$ concentrations, as mentioned above. Thus the timing of the topmost travertine sequence has to be taken with precaution due to the lack of precise ages.

Figure 4 summarizes the dating results. Overall, accepted U-series ages range from 11,500 years at the base of the travertine to $\sim 6000$ years at the topmost layers. Ages decrease from bottom to top as expected from the structure of the travertine deposit, but secular variations of U-series ages are significant throughout the profile.
Within the basal unit between 14.2 to $12 \mathrm{~m}$ depth Useries ages oscillate between 10,000 $(\mathrm{N}=3)$ and 11,500 $(\mathrm{N}=4)$ years BP. It is important to note here that we have measured at $12.3 \mathrm{~m}$ depth a travertine sample (LS2t) containing mostly primary micrite and a calcite cement (LS2c) reflecting solely the precipitation of second or third generation calcite as laminated palisade cement. Both carbonate phases differ by 800 years in age with the cement sample being much younger. This result clearly demonstrates the impact of secondary filling of pore space that causes secular variations in $\mathrm{U}$-series ages and isotopic composition as we will discuss later. At 12.3 to $12.6 \mathrm{~m}$ depth carbonate is precipitated at the selected sites in stagnant waters, causing the deposition of reed-encrusted tufa, which has not been dated by U-series dating. Above this layer from $12.6 \mathrm{~m}$ to roughly $9.5 \mathrm{~m}$ depth ages of the laminar travertine are slightly younger compared to the unit below

Fig. 4: U-series ages of the Bad Langensalza travertine deposit: Core Milchgasse and outcrop City Center. Gray and open squares denote $\mathrm{U}$-series ages that have been corrected for detrital Th-contamination using a ${ }^{230} \mathrm{Th} /{ }^{232} \mathrm{Th}$ activity ratio of $0.746 \mathrm{~b} \pm 0.3$. Triangles represent uncorrected U-series ages. Five U-series measurements have been rejected for this age-depth plot, because the travertine fabric of these samples clearly indicated strong deposition of Fe-Mn oxides, organic matter, and dissolution. Four of the five rejected analyses came from the upper travertine section in which carbonate precipitation alternates with alluvial clays and in which travertine is highly porous and fine grain carbonate sands are frequent.

Fig. 4: Ages U/Th obtenus pour le site Bad Langensalza: forage Milchgasse et carrière voisine. Les carrés gris indiquent des âges U/Th corrigés de la contamination en Thorium détritique en utilisant un rapport d'activité de ${ }^{230} \mathrm{Th}^{232} \mathrm{Th}$-détritique de $0.746 \pm 0.03$. Les triangles indiquent les âges U/Th non corrigés. Cinq âges U/Th ont été rejetés dans ce graphique âge - profondeur, car les échantillons ont révélé des traces de dissolution, de précipitation d'oxyde de fer et manganèse et de matière organique significatives. Quatre de ces cinq échantillons proviennent de la section supérieure du travertin, très poreuse, dans laquelle la précipitation de carbonate se fait en alternance avec un dépôt d'argile alluviale et de sable carbonaté. 
ranging between $10,500(\mathrm{~N}=6)$ to $9500(\mathrm{~N}=2)$ years $\mathrm{BP}$ indicating almost continues accumulation of carbonate with respect to the laminar travertine underneath it. However, U-series ages seem to oscillate as well between higher and lower ages, but differences are small within error. At $9.5 \mathrm{~m}$ loose material was flushed out of the drill core so the recovered travertine pieces did not fit together. The layer of loose carbonate sands was also observed at similar depth $( \pm 0.3 \mathrm{~m})$ in the main quarry. At this depth we observe a first, but barely marked change of U-series ages, as U-series ages above it (9.5 to $5.4 \mathrm{~m}$ depth) now vary between $\sim 8000$ years $(\mathrm{N}=5)$ and $\sim 9500$ years $(\mathrm{N}=6)$. Thus, the carbonate sand layer may indicate a local interruption of carbonate accumulation and erosion some time between 9000 and 10,000 years BP. Above this intermediate laminar travertine unit at $<5.4 \mathrm{~m}$ depth the texture of the travertine changes dramatically as laid out in the description of the site.

This major change in travertine deposition clearly marks an important growth interruption of at least 1000 years duration between 8500 and 7000 years BP. Within the topmost section (5.4 $\mathrm{m}$ to $2 \mathrm{~m}$ depth) U-series dating is not evident as carbonate accumulation is frequently intersected with alluvial clays, carbonate sands, and organic matter rich mud causing significant perturbation of the U-series system. However, the most reliable ages indicate carbonate accumulation likely between 7000 to 5800 years BP. No ages younger than 5800 years have been determined probably indicating the timing ones carbonate deposition ceased "at the investigated sites".

\section{5 - DISCUSSION}

Travertine precipitation from carbonate rich groundwater is a complex process during which inorganic precipitation through $\mathrm{CO}_{2}$ loss and bacterial induced carbonate precipitation interacts, in an environment of high groundwater discharge. Within the Thuringia basin travertine formation is frequent and well known for the Pleistocene, as vast travertine deposits extending over several square kilometers and having thicknesses of more than 10 to $20 \mathrm{~m}$ have been accumulated. The most intensely studied sites are at Bilzingsleben, Burgtonna, Weimar, Weimar Ehringsdorf, and Bad Langensalza, at which travertine was build up at least during the past 300000 years. In particular at Bad Langensalza travertine accumulation occurred during most of the Holocene originating from spring water along the major fault system of the Thuringia Basin. In contrast, modern tufa formation is known solely in a few rare places and travertine formation is absent. Travertine accumulated in most of the places cited above as so called meteogene travertine from spring water enriched in $\mathrm{CO}_{2}$ mostly from soil organic matter decomposition as little is known about potential occurrence of thermal groundwater or other $\mathrm{CO}_{2}$ sources, such as of volcanic origin. Thus, travertine accumulation must be related to some extend to the local to regional environmental conditions in the Thuringia Basin, such as mean annual temperatures, precipitation, and vegetation cover. The fact that modern travertine deposition is absent or occurs solely as carbonate tufa must therefore be related to changes of environmental conditions and/or human activity. Our detailed survey of U-series ages have revealed that travertine formation in Bad Langensalza started during the early Holocene likely right after the Younger Dryas cooling event at 11000 years BP. Carbonate formation occurred directly on the glacial gravel bed of the river Salza, with no indication of a prior warm episode during which alluvial clay could have been deposited. Thus no evidence was found for precipitation of carbonate during B $\varnothing$ lling-Allerød pre-Holocene warm climate. Travertine formation continued throughout the early Holocene until $\sim 8000$ years with a mean accumulation rate of $3 \mathrm{~mm}$ per year. However, U-series ages oscillate between higher and lower values within each textural travertine section, without obvious reason from weathering, U-series open system behavior, or depending on non-carbonate contamination and initial ${ }^{230} \mathrm{Th}$. Consequently, the obtained growth record can only be interpreted as initial carbonate formation being followed by second and third generation carbonate precipitation from pore fluids (cement or spar) infilling the pore space and dead volume. It is in particular stunning that lower ages observed in a travertine textural unit correspond to the highest ages of the unit just above, clearly indicating that continues growth of travertine layers results in successive infilling of the pore space underneath the presently active travertine accumulation. From such an at least bimodal carbonate precipitation pattern we estimate the accumulation rate for the basal units between $14.5 \mathrm{~m}$ and $9.5 \mathrm{~m}$ depth to be in the order of $5 \pm 1 \mathrm{~mm}$ per year $(11000-10000$ years $)$ and for the unit between $9.5 \mathrm{~m}$ and $5.5 \mathrm{~m}$ depth to be almost twice as high at $8 \pm 2 \mathrm{~mm}$ per year $(9500-8500$ years). Then secondary infilling of pore space continued likely for another $500-1000$ years during which the carbonate platform at the two selected sites did not further develop or was partly eroded. Then, a growth interruption of approximately $500-1000$ years becomes clearly evident as marked by the important textural change from almost laminar travertine layers to layers intersected with alluvial clays, organic matter rich mud, and carbonate sands that precipitated between 7000 and 5500 years. However, based on the obtained age distribution at two randomly selected sites, which are in addition closely situated we can not infer a carbonate precipitation model for the far more complex 3 dimensional structure of this travertine platform extending over several square kilometers. Thus, all interpretations of carbonate deposition in light of changing environmental conditions seem presently limited by the lack of constrain on the 3D age structure.

Besides the age distribution we have found that the U-isotopic composition, i.e. $\delta^{234} \mathrm{U}$, does dramatically change within the travertine sequence (fig. 3b). For 
most of the travertine profile $\delta^{234} \mathrm{U}$ values are restricted to $920 \pm 40 \%$ o, with two exceptions (see results, tab. 1). Then, at the marked change in texture at $5.4 \mathrm{~m}$ depth, values of $\delta^{234} \mathrm{U}$ drop to $750 \%$ and remain low for the topmost section (fig. 3b). Such a systematic change in $\mathrm{U}$-isotopic composition can only be explained through changes in U-isotopic composition of the source waters as U-fractionation during diagenesis and recoil processes can not explain such a significant drop in isotopic composition $(-200 \%$ ) over such small time scales. In addition, changes of groundwater U-isotopic composition through time are likely to occur as the U-isotopic composition depends on the weathering of $U$ from the host rocks - here limestone and the overlying soil which is driven by the groundwater residence time and its geochemical composition. $U$ is weathered from a host rock causing elevated $\delta^{234} U$ in the case were the $U$ supplying minerals are solely partly dissolved. This is a consequence of the alpha-recoil process during ${ }^{238} \mathrm{U}$ decay within the host rock, which results in a higher mobility of the decay product ${ }^{234} \mathrm{U}$. In contrast, if the host rock minerals supplying $U$ are completely dissolved no fractionation of ${ }^{238} \mathrm{U}$ and ${ }^{234} \mathrm{U}$ occurs and thus $\delta^{234} \mathrm{U} \sim$ $0 \%$ or negative. In case were the supplying minerals are partly dissolved the amount of ${ }^{234} \mathrm{U}$ excess depends on the time groundwater stays in contact with the aquifer assuming a constant geochemical composition, i.e. constant weathering conditions. Here, reduced residence times results in decreasing ${ }^{234} \mathrm{U}$ excess. However, changes in groundwater flow pattern, i.e. changes in host rock composition, or variable mixing of waters of different origin - shallow and deeper aquifers - can also steer variable U-isotopic composition. Finally, changes in the physico-chemical composition ( $\mathrm{T}, \mathrm{pH}$, alkalinity, $\mathrm{pCO}_{2}$, etc..) may cause variable weathering conditions and therefore variable U-isotopic composition for an even constant groundwater flow path and discharge rate. Thus, from the $\mathrm{U}$-isotopic composition of travertine alone and having in hand little information on the groundwater flow and geochemical composition we can barely identify whether changes in precipitation, vegetation cover, temperature, or alkalinity occurred as marked by the drop in U-isotopic composition and change in travertine texture. The texture of the carbonate platform may however give hinds on the environment in which carbonate was precipitated, but for the moment we are lacking a detailed survey of the topmost travertine layers which could identify whether the carbonate formed under different water flow conditions as compared to the deeper dense laminar travertine layers. Geochemical data not discussed here, however indicates little and in particular no systematic changes in travertine composition. For example, ${ }^{87} \mathrm{Sr} /{ }^{86} \mathrm{Sr}, \mathrm{Sr}$ and $\mathrm{Mg}$ concentrations vary little throughout the travertine sequence. Moreover, stable $\mathrm{C}$ and $\mathrm{O}$ isotopes have indicated significant variations with respect to the travertine texture, but no systematic changes as recorded by the $\mathrm{U}$-isotopic composition have been found (Frank, unpublished). Thus, to our present knowledge the composition of travertine precipitating waters did not dramatically change with respect to the significant change in U-isotopic composition. Thus, one may speculate whether in fact $\mathrm{U}$-isotopes record a reduction of the groundwater residence time, which would mean that groundwater flow and discharge increased during times of declining carbonate formation and finally ended some 5500 years ago. However, the interpretation of the $\mathrm{U}$ isotopic data in light of changes in groundwater flow remains speculative. Despite the lack of understanding how environmental conditions changed during the final stage of travertine formation it remains stunning that changes in U-isotopic composition are coincident to major changes in travertine texture.

\section{6 - CONCLUSION}

Travertine deposits at Bad Langensalza (Thuringia basin, Germany) grew with high accumulation rates of up to $8 \mathrm{~mm} \mathrm{yr}^{-1}$ during the early Holocene from 11500 years until about 5800 years. The resulting travertine record reflects initial carbonate precipitation followed by continues infilling of the initial pore space and dead volume with second and third generation calcite minerals. This record confirms that northern European travertine formation is restricted to short episodes of particular environmental conditions within a climate warm stage as previously suggested by Frank et al. (Frank et al., 2000) and Mallick and Frank (Mallick \& Frank, 2002) for marine isotope stage 5.5 and 5.3. We found no evidence of travertine accumulation within the late Holocene $(<5800$ years) nor during the very early Holocene warming (Bølling-Allerød), which may reflect missing accessibility or absence of carbonate precipitation as a result of unfavorable environmental changes.

Significant changes in travertine texture are accompanied by changes in $U$ isotopic composition of the carbonate indicating either changes of U supply from the host rock, i.e. variable weathering, or changes in groundwater residence time and flow path.

Thus systematic variations of the $\mathrm{U}$ isotopic composition in older travertine deposits such as the one of Burgtonna (MIS 5.5) (Mallick \& Frank, 2002) are likely due to changes in groundwater chemistry rather than reflecting $\mathrm{U}$ isotope fractionation related to $\mathrm{U}$ series system opening through diagenesis and recoil processes.

In summary further investigations are needed to better constrain the complex 3D age structure of the travertine deposits at Bad Langensalza and to elucidate the impact of climate and environmental change during the Holocene on the geochemical composition of the travertine layers. 


\section{ACKNOWLEDGEMENTS}

We thank Klaus-Dieter Jäger and Dietrich Mania for having broad our attention to the investigated site Bad Langensalza. We also acknowledge Sybille Reuter, Ulrich Hambach, and Ronzon Mallick for their help collecting the samples. We are grateful to enterprise TRACO at Bad Langensalza for their support to perform the drilling at site Milchgasse and the fact that we could easily access the outcrop nearby the drill site. We further acknowledge the helpful comments of P. Deschamps and an anonymous reviewer. This project was funded by the "Deutsche Forschungsgemeinschaft" (DFG), grant: MA 821/16-1 and the Heildelberger Akademie der Wissenschaft

\section{REFERENCES}

ADAM K. D., 1986 - Fossilfunde aus dem Cannstatter Sauerwasserkalken. Fundberichte aus Baden-Wuerrtemberg, 11, 25-61.

BLACKWELL B., \& SCHWARCZ H.S., 1986 - U-series analyses of the lower travertine at Ehringsdorf, DDR. Quaternary Research, 25, 215-222.

BRUNNACKER K., HENNIG G.J., JUVIGNÉ E., LÖHR H., URBAN B., \& ZEESE R., 1982 - Der Kartstein-Travertin in der nördlichen Westeifel. Decheniana, 135, 179-204.

BRUNNACKER K., JÄGER K.D., HENNIG G.J., PREUSS J., \& GRÜN R., 1983 - Radiometrische Untersuchungen zur Datierung mitteleuropäischer Travertinvorkommen. EAZ EthnographischArchäologische Zeitung, 24, 217-266.

CHENG H., EDWARDS R.L., HOFF J., GALLUP C.D. RICHARDS D.A., \& ASMERON Y., 2000 - The half-lives of uranium-234 and thorium-230. Chemical Geology, 169, 17-33.

DELANGHE D., BARD E., \& HAMELIN B., 2002 - New TIMS constraints on the uranium-238 and uranium-234 in seawaters from the main ocean basins and the Mediterranean Sea. Marine Chemistry, 80, 79-93.

EISENHAUER A., ZHU Z.R., COLLINS L.B., WYRWOLL K.H., \& EICHSTÄDTER R., 1996 - The last interglacial sea level change : new evidence from the Abrolhos islands, West Australia. Geologische Rundschau, 85, 606-614.

FEHLER A., 1998 - Die Travertine von Bad Langensalza Thüringen. Verlag Rockstuhl, Bad Langensalza.

FRANK N., 1997 - Anwendung der Thermionen-Massenspektrometrie zur Uran-Reihendatierung pleistozäner, mitteleuropäischer Travertinvorkommen. Unpublished Dissertation thesis, Univeristy Heidelberg.

FRANK N., BRAUN M., HAMBACH U., MANGINI A., \& WAGNER G., 2000 - Warm period growth of travertine during the last interglaciation in southern Germany. Quaternary Research, 54, 38-48.

GALLUP C. D., CHENG H., TAYLOR F.W., \& EDWARDS R. L. 2002 - Direct determination of the timing of sea level change during Termination II. Science, 295, 310-313.

GALLUP C.D., EDWARDS L., \& JOHNSON R.G., 1994 - The timing of high sea levels over the past 200,000 years. Science, 263, 796-800.

GREWE K., 1987 - Hoehlenvermessung am Beispiel der Kartsteinhoehlen. Karst und Hoehle, 1986/1987, 155-163.

HARMON R.S., GLAZEK J., \& NOWAK K., 1980 - 230Th/234U dating of travertine from the Bilzingsleben archeological site. $\mathrm{Na}$ ture, 284, 132-135.
HENDERSON G.M., 2002 - Seawater $\left({ }^{234} U /{ }^{238} U\right)$ during the last 800 thousand years. Earth and Planetary Science Letters, 199, 97 110 .

HENDERSON G.M., \& SLOWEY N. C., 2000 - Evidence from UTh dating against northern hemisphere forcing of the penultimate deglaciation. Nature, 404, 61-68.

IVANOVICH M., \& HARMON R.S., 1992 - Uranium-series disequilibrium: Applications to earth, marine, and environmental sciences. Clarendon Press, Oxford.

KAUFMAN A., 1993 - An evaluation of several methods for determining ${ }^{230} \mathrm{Th} / \mathrm{U}$ ages in impure carbonates. Geochimica et Cosmochimica Acta, 57, 2303-2317.

LIN J.C., BROECKER W.S., ANDERSON R.F., HEMMING S. RUBENSTONE J.L., \& BONANI G., 1996 - New ${ }^{230} \mathrm{Th} / \mathrm{U}$ and ${ }^{14} \mathrm{C}$ ages from Lake Lahontan carbonates, Nevada, USA, and a discussion of the origin of initial thorium. Geochimica et Cosmochimica Acta, 60, 2817-2832.

LUDWIG K.R., 2001 - ISOPLOT 2.49. Berkeley Geochronological Center special Publication, 1a, 58.

LUDWIG K.R., \& TITTERINGTON D.M., 1994 - Calculation of ${ }^{230} \mathrm{Th} / \mathrm{U}$ isochrons, ages, and errors. Geochimica et Cosmochimica Acta, 58, 5031-5042.

MALLICK R., 2000 - Entwicklung einer Mikrobeprobung zur Th/U Datierung und Anwendung an quartären Travertinen aus dem Thüringer Becken. University Heidelberg.

MALLICK R., \& FRANK N., 2002 - A new technique for precise Uranium-series dating of travertine micro-samples. Geochimica et Cosmochimica Acta, 66, 4261-4272.

REIFF W., 1986 - Die Sauerwasserkalke von Stuttgart. Fundberichte aus Baden-Wuertemberg, 11, 2-24.

SCHOLZ D., MANGINI A., \& FELIS T., 2004 - U-series dating of diagenetically altered fossil reef corals. Earth and Planetary Science Letters, 218, 163-178.

SCHWARCZ H.O., GRÜN R., LATHAM A.G., MANIA D., \& BRUNNACKER K., 1988 - The Bilzingsleben archaeological site : new dating evidence. Archaeometry, 30, 5-17.

SCHWARCZ H.P., 1980 - Absolute age determination of archaeological sotes by uranium series dating of travertines. Archaeometry, 22, 3-24.

SOMMERMEIER L., 1913 - Der Kartstein und der Kalktuff von Dreihmuehlen bei Eisfrey in der Eifel. Sonder-Abdruck aus den Verhandlungen des Naturhistorischen Vereins der preuss, Rheinlande und Westfalens, 70, 302-333.

SRDOC D., OSMOND J.K., HORVATINCIC N., DABOUS A.A., \& OBELIC B., 1994 - Radiocarbon and uranium-series dating of Plitvice lakes travertines. Radiocarbon, 36, 203-219.

STURCHIO N.C., PIERCE K.L., MURRELL M.T, \& SOREY M.L., 1994 - Uranium-series ages of travertines and timing of the last glaciation in the Northern Yellowstone Area, Wyoming-Montana. Quaternary Research, 41, 265-277.

THOMPSON W.G., SPIEGELMAN M.W., GOLDSTEIN S.L., \& SPEED R.C., 2003 - An open-system model for U-series age determinations of fossil corals. Earth and Planetary Science Letters 210, 365-381.

VILLEMANT B., \& FEUILLET N., 2003 - Dating open systems by the ${ }^{238} \mathrm{U}_{-}{ }^{234} \mathrm{U}_{-}{ }^{230} \mathrm{Th}$ method : application to Quaternary reef terraces. Earth and Planetary Science Letters, 210, 105-118.

WEDEPOHL K.H., 1995 - The composition of the continental crust. Geochimica et Cosmochimica Acta, 59, 1217-1232. 